\title{
GETTING TO THE TOP OF MIND: HOW REMINDERS INCREASE SAVING
}

\author{
Dean Karlan, Margaret McConnell, Sendhil Mullainathan, and Jonathan Zinman
}

CRR WP 2010-4

Released: April 2010

Date Submitted: April 2010

Center for Retirement Research at Boston College (CRR)

Hovey House

140 Commonwealth Avenue

Chestnut Hill, MA 02467

Tel: 617-552-1762 Fax: 617-552-0191

The research reported herein was pursuant to a grant from the U.S. Social Security Administration (SSA) funded as part of the Retirement Research Consortium (RRC). This grant was awarded through the CRR's Steven H. Sandell Grant Program for Junior Scholars in Retirement Research. The findings and conclusions expressed are solely those of the authors and do not represent the views of SSA, any agency of the Federal Government, the RRC, Yale University, Harvard University, Dartmouth University, or Boston College.

(C) 2010, by Dean Karlan, Margaret McConnell, Sendhil Mullainathan, and Jonathan Zinman. All rights reserved. Short sections of text, not to exceed two paragraphs, may be quoted without explicit permission provided that full credit, including @ $@$ notice, is given to the source. 


\title{
About the Sandell Grant Program
}

This paper received funding from the Steven H. Sandell Grant Program for Junior Scholars in Retirement Research. Established in 1999, the Sandell program's purpose is to promote research on retirement issues by scholars in a wide variety of disciplines, including actuarial science, demography, economics, finance, gerontology, political science, psychology, public administration, public policy, sociology, social work, and statistics. The program is funded through a grant from the Social Security Administration (SSA). For more information on the Sandell program, please visit our web site at http://crr.bc.edu/opportunities/steven_h._sandell_grant_program_2.html, send e-mail to crr@bc.edu, or call Marina Tsiknis at (617) 552-1092.

\section{About the Center for Retirement Research}

The Center for Retirement Research at Boston College, part of a consortium that includes parallel centers at the University of Michigan and the National Bureau of Economic Research, was established in 1998 through a grant from the Social Security Administration. The Center's mission is to produce first-class research and forge a strong link between the academic community and decision makers in the public and private sectors around an issue of critical importance to the nation's future. To achieve this mission, the Center sponsors a wide variety of research projects, transmits new findings to a broad audience, trains new scholars, and broadens access to valuable data sources.

\author{
Center for Retirement Research at Boston College \\ Hovey House \\ 140 Commonwealth Avenue \\ Chestnut Hill, MA 02467 \\ phone: 617-552-1762 fax: 617-552-0191 \\ e-mail: crr@bc.edu \\ www.bc.edu/crr
}

Affiliated Institutions:

The Brookings Institution

Massachusetts Institute of Technology

Syracuse University

Urban Institute 


\begin{abstract}
We develop and test a simple model of limited attention in intertemporal choice.

The model posits that individuals fully attend to consumption in all periods but fail to attend to some future lumpy expenditure opportunities. This asymmetry generates some predictions that overlap with other models of present-bias. Our model also generates the unique predictions that reminders will increase saving, and that a reminder that makes a specific expenditure more salient will be especially effective. We find support for these predictions in three field experiments that randomly assign reminders to new savings account holders.
\end{abstract}




\section{Introduction}

Consumption, savings and borrowing behavior is sometimes difficult to reconcile with traditional models of intertemporal choice. Calibrations of U.S. data suggest that extremely high short-term discount rates are necessary to explain observed borrowing patterns (Laibson, Repetto and Tobacman 2007). Voluntary commitment devices help increase savings (Ashraf, Karlan and Yin 2006; Benartzi and Thaler 2004). Default options have large effects on retirement savings decisions (Madrian and Shea 2001; Beshears et al 2009). These patterns are often explained by models that emphasize time inconsistency and self-control problems (Laibson 1997; O’Donoghue and Rabin 1999; Fudenberg and Levine 2006; Banerjee and Mullainathan 2009). In such models, people can exhibit both impatience and patience, depending on the horizon or good of choice.

We develop some theory and evidence that a different psychology - limited attention - also plays an important role in explaining these types of intertemporal choices. In most models, deciding what to consume today requires a consideration of all future expenditure opportunities; e.g., how much in school fees or taxes are coming due? What novel consumption opportunities will arise? In our model, individuals overlook some of these future expenditure opportunities. We are motivated in part by the "planning fallacy:" people systematically underestimate the time required to complete tasks (Buehler, Griffin and Ross 2002). But prodding people to list specific sub-components of tasks improves the accuracy of time-completion estimates (Forsythe and Burt 2008). This evidence illustrates the potential for overlooking specific items when making plans.

We provide a simple model of lifetime consumption and savings that incorporates an attentional failure. ${ }^{1}$ Individuals face two kinds of consumption opportunities each period: 1) regular consumption spending and 2) a lumpy expenditure, which occurs with certainty but can differ in each period. For example, the expenditure opportunity may be school fees in one period, car registration in another

\footnotetext{
${ }^{1}$ Macroeconomists have proposed that costly information processing capability may lead to "rational inattention" (Sims 1998 and 2003; Mankiw and Reis 2002; Ball, et al 2005; Reis 2006). In Gabaix and Laibson (2006) consumers may not (fully) attend to future, state-contingent prices. In Chetty, Looney and Kroft (2009) agents are attentive only to posted prices. These theoretical models have found empirical support; see DellaVigna (2009) for a review of the field evidence. While these models emphasize inattention to prices or some component of the price vector, our model emphasizes inattention to future consumption opportunities. Banerjee and Mullainathan (2008) proposes a theoretical model in which individuals allocate scarce attention between problems at home and problems at work, leading to a poverty trap.
} 
period, and a night out in the next. For simplicity, we assume that regular consumption spending has no foresight problems but that lumpy expenditures are overlooked with some probability. ${ }^{2}$ In any period individuals choose consumption to maximize their lifetime utility given the future expenditure opportunities they "attend" to. ${ }^{3}$ The failure to forecast some future expenditure opportunities can distort intertemporal allocations by leading to less smoothing (via more borrowing and/or less saving) than would occur under perfect or unbiased foresight.

A simple example illustrates our model. Suppose you hear that your favorite singer is coming to town three months from now. You decide to go, and mark the concert date in your calendar. Tickets will not go on sale until the night of the show. Ideally, if your utility is concave with respect to consumption, you would finance the ticket by smoothing the expenditure shock over your lifetime - including some saving over the next three months. But if you are inattentive as in our model, you may sometimes forget your concert plan and choose to consume instead of save. Then, when the day of the concert arrives, you face the second-best options of forgoing the concert or financing it disproportionately through debt (e.g., by charging it to a credit card or incurring a checking account overdraft fee) and thus reducing future consumption even more in order to cover the financing costs. This sort of attentional failure may or may not be consequential in isolation. But lifetime consumption allocations are the result of countless such decisions, and small distortions can add up (and compound). Now suppose there is a reminders technology (e.g., in your personal digital assistant, or from a third-party as in Appendix Figure 1). Periodic reminder messages induce you to attend to the benefits and task of putting money aside for the concert, and thereby help you increase incremental savings and long-run smoothing.

This example also highlights how our model relates to other findings and behavioral models. Savings deposit collection services may be effective because they serve as reminders (Ashraf, Karlan and Yin 2006a; Dupas and Robinson 2009). Likewise, surveys may induce saving and investment behaviors because they serve as reminders or as a shock to attention (Stango and Zinman 2010;

\footnotetext{
${ }^{2}$ This asymmetry is a stark way of creating a wedge between more vs. less routine consumption (e.g., daily food vs. annual car registration fee).

${ }^{3}$ Our setup is related to Mullainathan (1999), where individuals fail to remember information that predicted future income, and to Schwartzstein (2009), where individuals may mistakenly only attend to information that they consider relevant for a prediction task.
} 
Zwane et al 2010). Non-binding commitments may be effective because they operate on attention, rather than on self-control with large transaction costs for undoing the commitment (e.g., default options or automatic enrollment features in retirement saving; prepaid fertilizer sales as in Duflo, Kremer, and Robinson 2009). Indeed our model generates undersaving, and an ensuing inability to take-up some high-return lumpy investments or high-utility lumpy expenditures, without any role for (time-varying) impatience or commitment. Our model also suggests that overborrowing may occur in part because debt can be "salience-advantaged" relative to saving; e.g., when debt is available "on-demand," at the moment when a lumpy expenditure opportunity arises (unexpectedly, due to limited attention) and is (momentarily) at the "top of mind."

Perhaps the starkest difference between our model and other (behavioral) models is our key role for reminders. Reminders change intertemporal allocations, and improve consumer welfare, by providing associations between future expenditure opportunities and today's choices that mitigate the attentional failure. ${ }^{4}$ Our model generates two related testable predictions: 1) Reminders will increase saving; 2) Reminders will be particularly effective when they draw attention to a particular future goal or opportunity; in this respect our model provides a novel potential microfoundation for mental accounting (Thaler 1990). Instead of offering a weak counter to temptation, mental labels provide a strong association between today's saving(s) and specific future events, increasing the probability that individuals attend to those events when choosing consumption, and thereby improving smoothing.

We test our model's predictions about reminders in field experiments with three different banks in Bolivia, Peru, and the Philippines. In each experiment, individuals opened a bank savings account which included varying degrees of incentives or commitment features designed to encourage individuals to reach a savings goal. Some individuals were randomly assigned to receive a monthly

\footnotetext{
${ }^{4}$ Our predictions on reminders have some similarities to cue-based models (Laibson 2001). But our setup is distinct both motivationally and formally. Motivationally, work on cues has focused on the role of external stimuli in triggering consumption desires, following a large body of psychological evidence on cravings and conditioning. We focus on the role of external events -reminders - that focus attention on future expenditure opportunities, leading to savings. Formally: 1) limited attention can lead to both ex-ante and ex-post mistakes in our model, whereas in preference-based models individuals might consider consumption choices to be a mistake only ex-post; 2) neither past consumption nor past reminders influence current decisions in our model. In cue theory, the past matters because cues develop from learned, Pavlovian associations between external stimuli and consumption.
} 
reminder via text message or letter, while a control group received no reminder. Reminders increased the likelihood of reaching a savings goal by $3 \%$ and the total amount saved in the reminding bank by $6 \%$. This effect size is comparable to that found for commitment savings on a similar sample in the Philippines (Ashraf, Karlan and Yin 2006a). ${ }^{5}$ Reminders that highlighted the client's particular goal - i.e., reminders that made a particular future expenditure opportunity, like school fees, more salient - were two times more effective than reminders that did not mention the goal. These findings are novel empirical evidence on the importance of reminders in household finance, and build on evidence from several clinical trials on patient and clinician behaviors. ${ }^{6}$

Our theory, evidence, and applications have some limitations. We do not model awareness of or competition for limited attention. We do not make specific predictions about what kind of events most effectively increase attention. Indeed, we tested several other treatments that could be interpreted as attention treatments that, unlike reminders, had no effect on saving. Our experimental results do not cover the household's full balance sheet, and we cannot make precise statements about whether and how much reminders increased total savings or changed consumer welfare in our sample. Our sample is comprised of people who had already signed up to save of their own volition, thus we do not answer the interesting question of whether attention treatments would differ for non-savers. Nevertheless our theory and evidence provide novel evidence that limited attention may be an important driver of intertemporal choice. The paper proceeds as follows. Section II details our main theoretical model and predictions. Section III discusses some additional applications. Section IV details the settings and design of our field tests. Section V presents the results. Section VI concludes.

\section{Model}

We model individual consumption over a finite horizon period with $3 \leq T<\infty$. In each period, individuals receive constant income $y$. We assume for simplicity that individuals do not discount the future so that the discount rate $\delta=1$.

Individuals derive utility from consumption and from discrete ("lumpy") expenditure opportu-

\footnotetext{
${ }^{5}$ The commitment savings treatment in Ashraf et al (2006a) increased short-term savings balances by an average of 49 pesos $(7 \%)$ relative to the control group treatment.

${ }^{6}$ See van Dulmen et al (2007) and Krishna et al (2009) for a review of evidence on the impact of reminders on adherence.
} 
nities. The utility from consumption spending is represented by the function $u$ which is increasing and concave in consumption. Individuals face one expenditure opportunity in every period. Lumpy expenditure opportunities differ in terms of their composition in each time period (e.g., medical one period, car registration the next), but always have a unit cost of 1 . Individuals who pay a unit cost to finance the opportunity faced in the current period receive additive utility $\bar{u}$. The decision about whether to pay for the opportunity is represented by the binary variable $x_{t}$, where $x_{t}=1$ if individuals finance the expenditure opportunity and $x_{t}=0$ otherwise.

To maximize lifetime utility, individuals choose current period consumption $c_{t}$ and whether to satisfy the expenditure opportunity $x_{t}$.

$$
\sum_{t=1}^{T}\left(u\left(c_{t}\right)+x_{t} \bar{u}\right)
$$

subject to:

$$
\begin{aligned}
w_{t+1} & =w_{t}+y-c_{t}-x_{t} \text { for all } t \\
w_{1} & =0 \text { and } w_{T+1}=0
\end{aligned}
$$

where $w_{t}$ represents the wealth at the start of a period. We assume that individuals start and end with zero wealth. Individuals may save or borrow, and we assume that borrowed money must be repaid by life's end. For simplicity, we assume that there is no interest charged on loans or earned on savings.

\section{Full Attention Benchmark}

Fully "attentive" individuals correctly forecast all future expenditure opportunities from the first period, and, given concavity with respect to consumption, will optimize by smoothing: $c_{t}=c^{*}$ in all periods. We can see by backward induction that the level of optimal consumption $c^{*}$ will be a function of the number of expenditures financed.

$$
c^{*}=y-\left(\sum_{t=1}^{T} x_{t}\right) / T
$$


Let us denote $k_{t}=\sum_{\tau=t+1}^{T} x_{\tau}$ as the total number of future expenditures to be financed after $t$. The total number of expenditures satisfied will then be $k_{1}+x_{1}$. In the first period, individuals will optimally chose to satisfy $k_{1}^{*}+x_{1}^{*}$ lifetime expenditures such that:

$$
u^{\prime}\left(y-\frac{k_{1}^{*}+x_{1}^{*}}{T}\right) \leq \bar{u}<u^{\prime}\left(y-\frac{\left(k_{1}^{*}+x_{1}^{*}+1\right)}{T}\right)
$$

That is, individuals will finance expenditures until they are indifferent between the utility from financing an additional expenditure and the marginal utility from consumption (assuming individuals are not constrained by their lifetime income constraint $\left.k_{1}^{*}+x_{1}^{*} \leq T y\right)$. Perfectly attentive individuals will perfectly smooth their consumption by consuming $c_{t}=y-\frac{k_{1}^{*}+x_{1}^{*}}{T}$ in each period. For fully attentive individuals, consumption and savings plans will never deviate from the optimal plan made in the first period.

Without less of generality, we consider the notationally simple case of $k_{1}^{*}+x_{1}^{*}=T$ for the duration of the analysis (i.e., fully attentive individuals will purchase one lumpy expenditure in every time period in their lifetime). Wealth formation will therefore follow the process:

$$
w_{t+1}=w_{t}+y-c_{t}^{*}-x_{t}^{*}=w_{t}+\frac{T-1+1}{T}-1=w_{t}
$$

which implies $s_{t}^{*}=0$. We could instead assume that fully attentive individuals optimally purchase some fraction $\alpha \in[0,1]$ of expenditures, so that $k_{1}^{*}+x_{1}^{*}=\alpha T$. We could further specify that when indifferent, individuals always chose to purchase expenditures later in life, so that $\left\{x_{1}^{*}=0, x_{2}^{*}=\right.$ $\left.0, \ldots, x_{\alpha T}^{*}=1, \ldots, x_{T}^{*}=1\right\}$. With these two assumptions, we would predict positive savings for fully attentive individuals. Since borrowing and saving are symmetric in our model, we consider net savings (amount saved less amount borrowed) when considering comparative statics between fully attentive and inattentive consumers.

\section{InATtention to Future Expenditures}

In practice, individuals may not be fully attentive to all lumpy expenditure opportunities. Let us consider that inattentive individuals attend perfectly to consumption and current period expenditure 
opportunities, but only attend to future lumpy expenditure opportunities with some probability $\theta \in[0,1)$.

Inattentive individuals then choose their current period consumption $c_{t}$ and whether to satisfy current period expenditure $x_{t}$ in order maximize their lifetime utility, as perceived in that time period (i.e., considering only those lumpy expenditures they take into account in the current period).

$$
u\left(c_{t}\right)+x_{t} \bar{u}+\sum_{\tau=t+1}^{T}\left(\theta\left[u\left(c_{\tau}\right)+x_{\tau} \bar{u}\right]+(1-\theta) u\left(c_{\tau}\right)\right)
$$

subject to:

$$
\begin{aligned}
w_{t+1} & =w_{t}+y-c_{t}-x_{t} \text { for all } t \\
w_{0} & =0 \text { and } w_{T+1}=0
\end{aligned}
$$

We assume that individuals are unaware of their inattention to expenditures: people believe they are optimizing utility as they would in the rational model, but they actually underforecast the number of lumpy expenditure opportunities.

Inattentive individuals reoptimize their savings plan in every period depending on the realization of $\widetilde{K}_{t}$ which is a random variable representing the number of future expenditures an individual attends to in period $t$. $\widetilde{K}_{t}$ has expected value $E\left(\widetilde{K}_{t}\right)=\theta(T-t)$. Instead of saving the same fixed amount in each period, individuals will consider both their current period wealth and the set of future expenditures they attend to when choosing consumption. Because individuals may forecast a different number of future expenditures in every period, they must recalibrate their savings plan as they are faced with unexpected expenditures. In doing this, individuals will either forgo some lumpy expenditures (illustrated in example 1) or curtail consumption (illustrated in example 2), depending on how much utility individuals get from each lumpy expenditure $(\bar{u})$.

As with fully attentive individuals, concave utility implies that inattentive individuals will plan to smooth consumption so that $\widetilde{c}_{t}^{*}=\widetilde{c}_{\tau}^{*}$ for all $t, \tau$. By backward induction, we can see that consumption 
for the inattentive individual will be:

$$
\widetilde{c}_{t}=y+\left[\widetilde{w}_{t}-\widetilde{x}_{t}-\theta\left(\sum_{\tau=t+1}^{T} \widetilde{x}_{\tau}\right)\right] /(T-t+1)
$$

Let us denote the number of future expenditures an individual plans to purchase in period $t$ as: $\widetilde{k}_{t}=\theta \sum_{\tau=t+1}^{T} \widetilde{x}_{\tau}$. Individuals will choose whether to purchase the current expenditure $\left(\widetilde{x}_{t}^{*}\right)$ and plan to purchase future expenditures $\left(\widetilde{k}_{t}^{*}=\theta \sum_{\tau=t+1}^{T} \widetilde{x}_{\tau}^{*}\right)$ :

$$
u^{\prime}\left(y+\frac{\widetilde{w}_{t}-\left(\widetilde{k}_{t}^{*}+\widetilde{x}_{t}^{*}\right)}{T-t+1}\right) \leq \bar{u}<u^{\prime}\left(y+\frac{\widetilde{w}_{t}-\left(\widetilde{k}_{t}^{*}+\widetilde{x}_{t}^{*}+1\right)}{T-t+1}\right)
$$

Provided they are not constrained by their lifetime budget constraint in period $t\left(\widetilde{w}_{t}+\widetilde{k}_{t}^{*}+\widetilde{x}_{t}^{*} \leq\right.$ $[T-t+1] y)$, individuals will finance expenditures until they are indifferent between the utility from financing an additional expenditure and the marginal utility from consumption. ${ }^{7}$ While the model is agnostic about when expenditures will be financed, we make the notationally simple assumption that as long as individuals still gain positive marginal utility from financing expenditures, they will finance expenditures happening in the current period first. That is, as long as $\widetilde{k}_{t}^{*}+\widetilde{x}_{t}^{*} \geq 1, \widetilde{x}_{t}^{*}=1 .^{8}$

\section{SAVINGS AND INATTENTION}

The inattentive consumer's savings in period $t$ is:

$$
\widetilde{s}_{t}^{*}=\frac{\widetilde{k}_{t}^{*}+\widetilde{x}_{t}^{*}}{T-t+1}-\widetilde{x}_{t}^{*}
$$

We can now compare expected savings for inattentive and attentive individuals. Individuals can only plan to purchase weakly less than the future expenditures they foresee: $\widetilde{k}_{t}^{*} \leq \widetilde{K}_{t}$ Recall that in our full attention benchmark, the consumer simply spends her income in each period, for a constant

\footnotetext{
${ }^{7}$ When individuals are budget constrained they will plan to finance fewer expenditures than $k_{t}^{*}$ and the intuition of our main result remains the same.

${ }^{8}$ This assumption is made for ease of notation and is without loss of generality.
} 
savings rate of zero. In contrast the inattentive consumer borrows in some period(s):

$$
E\left(\widetilde{s}_{t}^{*}\right)=\frac{E\left(\widetilde{k}^{*}\right)+x_{t}^{*}}{T-t+1}-x_{t}^{*} \leq \frac{[\theta(T-t)+1]}{T-t+1}-1<0=s_{t}^{*}
$$

So the inattentive consumer has a negative expected savings rate that is lower than the full-attention consumer's.

\section{EXAMPLE}

Let us consider an example in three periods, $T=3$. Suppose that fully attentive individuals prefer to finance 3 expenditures. That is, suppose that

$$
3 u(y-1)+3 \bar{u}>3 u\left(y-\frac{2}{3}\right)+2 \bar{u}
$$

Now let us suppose that an inattentive consumer fails to attend to just one lumpy expenditure occurring in the future. Because she (incorrectly) forecasts only 2 total expenditures, she borrows to finance part of the expenditure she faces in period 1. In period 2, when faced with an unplanned expenditure, she realizes her mistake. The inattentive consumer then has two options: she can either cut consumption to finance all 3 expenditures or she can forgo one expenditure. She will finance an unexpected expenditure if and only if financing the expenditure affords greater utility than maintaining higher consumption. That is, she will finance the expenditure if and only if:

$$
u\left(y-\frac{2}{3}\right)+2 u\left(y-\frac{7}{6}\right)+3 \bar{u}>3 u\left(y-\frac{2}{3}\right)+2 \bar{u}
$$

Otherwise, she will forgo the unexpected expenditure and maintain consumption.

Inattention in the first period ultimately reduces lifetime utility, whether because of lower consumption (as illustrated in Figure 1) or through purchasing fewer total lumpy expenditures (as illustrated in Figure 2).

In models of self control, present biased preferences imply a relatively lower relative valuation of future consumption. In our model, individuals fundamentally misunderstand the value of future consumption. As with a model of self control, our model predicts that inattentive individuals will undersave or underborrow. However, our model also generates distinct predictions from the self 


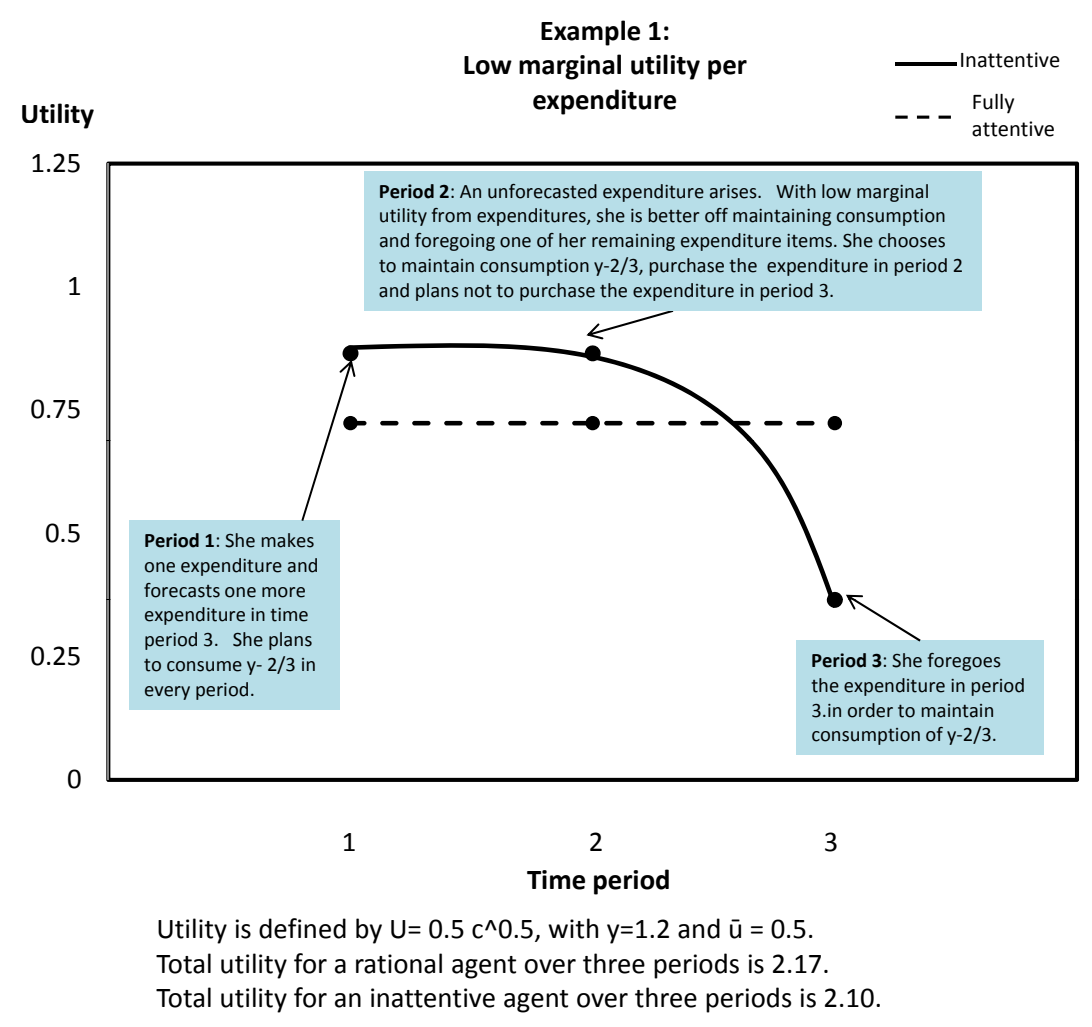

Figure 1: Model Example 1

control model which we will now discuss.

\section{REMINDERS}

In self-control models, individuals decide to consume more in the current period while fully accounting for all future expenditures. That is, individuals who are present-biased plan to undersave and or overborrow. Therefore, reminders should have no impact on the consumption decisions of individuals with self control problems. On the other hand, if individuals have inconsistent savings and consumption behavior because of lack of attention, we predict that reminders will increase savings.

We model reminders as an exogenous increase in the probability that individuals attend to future 


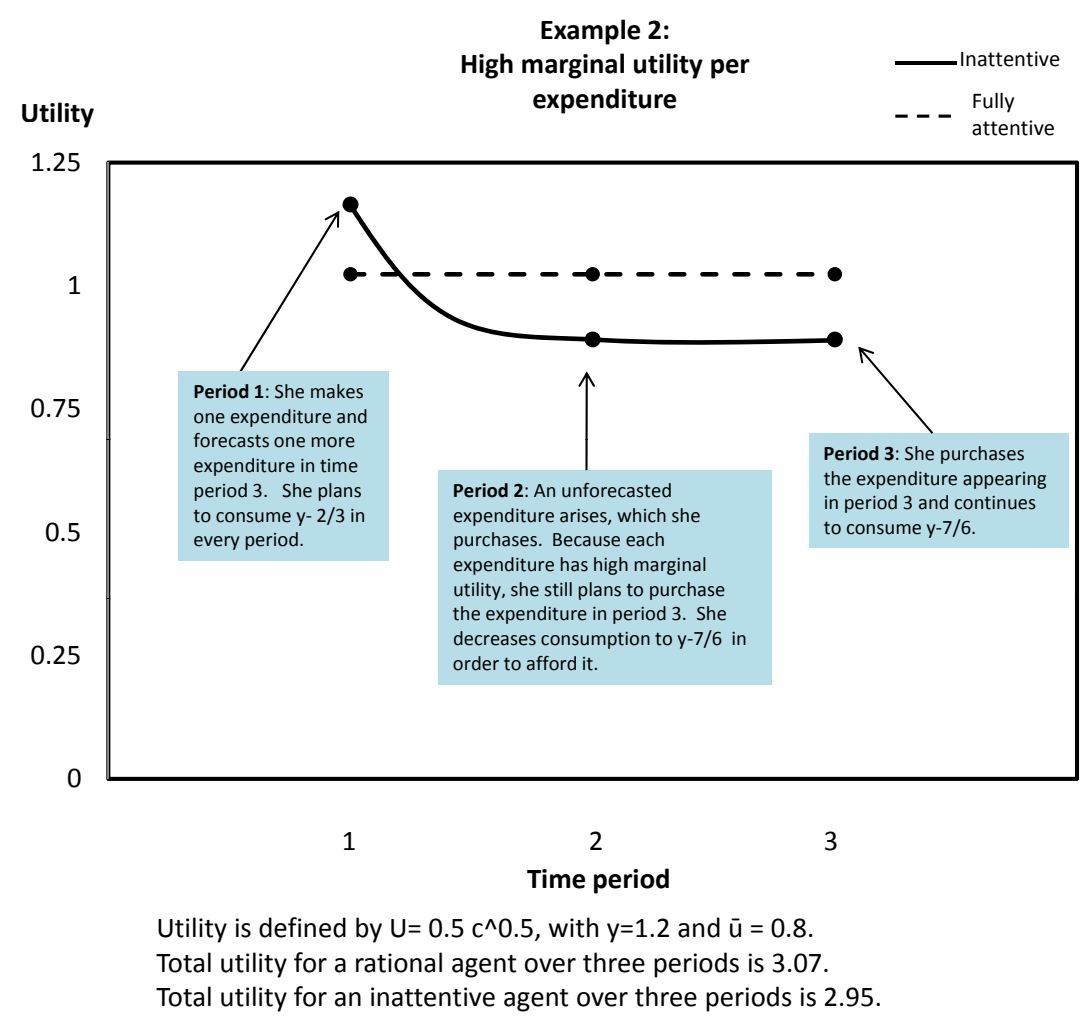

Figure 2: Model Example 2

lumpy expenditure opportunities: $\theta_{r}>\theta_{n r}$. In turn reminders affect the expected number of future expenditure opportunities attended to in a current period:

$$
\begin{gathered}
E_{n r}\left(\widetilde{K}_{t}\right)=\theta_{n r}(T-t) \\
E_{r}\left(\widetilde{K}_{t}\right)=\theta_{r}(T-t)
\end{gathered}
$$

with $E_{r}\left(\widetilde{K}_{t}\right)>E_{n r}\left(\widetilde{K}_{t}\right)$. As before, individuals only plan to purchase lumpy expenditures they foresee, and the optimal number of planned expenditures in future periods will be less than or 
equal to the number of expenditures attended to: $\widetilde{k}_{t}^{*} \leq \widetilde{K}_{t}$. Therefore the expected number of expenditures an individual plans to satisfy is higher in the presence of reminders: $E_{r}\left(\widetilde{k}_{t}^{*}\right)>E_{n r}\left(\widetilde{k}_{t}^{*}\right)$. From equation (1) we can then see that expected savings will be increasing in $\theta$, and hence higher after a reminder is introduced: $E_{r}\left(\widetilde{s}_{t}^{*}\right)>E_{n r}\left(\widetilde{s}_{t}^{*}\right)$.

Note that models of temptation would only make this prediction under the additional assumption that reminders affect preferences or the cost of self-control. Although this might be a natural assumption to make for reminders or other exogenous, Pavlovian stimuli for current consumption (Laibson 2001), there is little if any psychological or neurological evidence that such stimuli can change the marginal utility of saving (or future consumption). We test our model using randomly assigned reminders to save (see Section IV).

\section{Mental Accounting}

Our model also provides a potential microfoundation for mental accounting (Thaler 1990). Consumers often report that they create separate accounts (real or imagined) for different spending categories/goals and then constrain their spending based on individual account balances (rather than total balances). This behavior violates the standard assumption of fungibility of money (see DellaVigna 2009 for a review of related empirical evidence).

Our model helps explain why mental accounting might be a constrained optimum. For a limited attention consumer, an account label increases the "salience" of a specific future lumpy expenditure in the current period: i.e., the label may increase the likelihood of attending to the future expenditure and optimally smoothing for it. The Appendix provides a formal model of salience and its effects on attention. Less formally, define $\theta_{r}^{\tau}$ as the probability of attention when a reminder focuses on a specific future expenditure occurring in period $\tau$, so that $\theta_{r}^{\tau}>\theta_{r}$. Then the expected number of lumpy expenditures will be higher when individuals receive a reminder that focuses on a specific expenditure:

$$
\begin{aligned}
& E_{r}\left(\widetilde{K}_{t}\right)=\theta_{r}(T-t) \\
& E_{r}^{\tau}\left(\widetilde{K}_{t}\right)=\theta_{r}(T-t-1)+\theta_{r}^{\tau}
\end{aligned}
$$


Based on equation (1), we see that when individuals forecast more expenditures because of focusing on a specific expenditure $\left(E_{r}\left(\widetilde{K}_{t}\right)>E_{r}^{\tau}\left(\widetilde{K}_{t}\right)\right)$, expected savings will be higher : $E_{r}^{\tau}\left(\widetilde{s}_{t}^{*}\right)>E_{r}^{\tau}\left(\widetilde{s}_{t}^{*}\right)$.

So our model predicts that savings rates will be higher when reminders mention (or are otherwise associated with) a particular future expenditure. We test this prediction for a group of individuals who placed a label on their saving account ex-ante, by randomizing whether a reminder to save mentions the individual's chosen label. Please see Section V for the results.

\section{Time InCONSISTENCY}

Models based on time-inconsistent preferences do not generally predict that reminders to save will affect behavior. Yet empirically, measures of time-inconsistency are strongly correlated with more discretionary borrowing (Meier and Sprenger 2009) and less saving (Ashraf, Karlan and Yin 2006b). We find that reminders increase saving more for individuals who exhibit appear time-inconsistent ex-ante. Here we offer a way to reconcile these findings.

A common method for measuring time-inconsistency is to give individuals multiple hypothetical choices between a smaller payoff at time $t$ and a larger payoff at time $t+1$, where the choices vary $t$ (e.g., $t$ might be "today" in one choice, and "six months from now" in another choice). When the same individual prefers the smaller payoff when $t=$ today, but prefers the larger payoff when $t$ is sometime in the future, we say that person is time-inconsistent.

But if individuals are credit constrained, such time-inconsistency may be borne of limited attention rather than preferences. To see this, consider a four-period example in our model. As in the scenarios used to measure time-inconsistency, individuals face a choice between receiving $A$ in period 1 and $B$ in period 2, where $A<B$. In addition, individuals must choose between $C$ in period 3 and $D$ in period 4 , where $C<D$. We modify our set-up by assuming that individuals are totally credit constrained: they cannot borrow. Furthermore, individuals' current period income $y$ is not enough to finance a lumpy expenditure: $y<1$. If the utility from the expenditure is high enough, a consumer will prefer the smaller payoff because it allows her to finance today's lumpy expenditure. 
Formally, she prefers the immediate payoff $A$ if:

$$
\bar{u} \geq\left[u(y)+3 u\left(y+\frac{B}{3}\right)\right]-4 u\left(y+\frac{A-1}{4}\right)
$$

Now consider a limited-attention consumer who does not forecast some future lumpy expenditure opportunities. She considers the stream of consumption benefits from the payoffs $C$ and $D$ but does not consider the payoffs' implications for financing unforeseen lumpy expenditure opportunities. To simplify, consider the case where the consumer does not forecast any of the future lumpy expenditure opportunities. Then if the consumption stream from the higher payoff $D$ is greater than the consumption stream from the payoff $C$, she prefers to wait for the higher payoff. Formally, she prefers $D$ in this case if:

$$
2 u(y)+2 u\left(y+\frac{C}{2}\right)<3 u(y)+u(y+D)
$$

Thus, limited attention can generate time-inconsistent choices over payoffs without any instability in preferences.

\section{Other Implications}

\section{Defaults}

Our model also helps interpret the effects of default options on retirement plan enrollment, organ donation and other decisions. Once enrolled, the default can "stick" in our model because the decision (or, more precisely, the option of undoing the decision) leaves the top of mind. In contrast, models with temptation requires time-varying costs of self-control to get sticky defaults.

\section{Fertilizer Purchase}

Evidence on fertilizer purchase and use from Duflo, Kremer and Robinson (2009) suggests that when visited by a program officer at harvest time, farmers are more likely to buy fertilizer and use this fertilizer at planting time, even when the fertilizer is delivered immediately after harvest and could therefore be resold before planting time. These results are consistent with a model of time inconsistency where there are costs to selling fertilizer. ${ }^{9}$ Choosing to have fertilizer delivered at

\footnotetext{
${ }^{9}$ These costs could be the costs of re-selling fertilizer or some stigma associated with selling fertilizer.
} 
harvest time could be seen as a form of commitment. However, these results are also consistent with a model of limited attention. The event of the visit by the program officer at harvest time is highly associated with the future expenditure of purchasing fertilizer at the next planting period. Without this event, farmers who have just finished planting would not be as likely to attend to all of the expenditures they would face in the next planting cycle. Once the farmers have purchased fertilizer, the fertilizer is perfectly associated with the need to use the fertilizer in planting periods, ensuring that fertilizer is not crowded out by other consumption between harvest and planting time. The fertilizer program allows farmers to prepare for future fertilizer expenditures without fully attending to them when choosing current consumption.

\section{Deposit Collection}

Evidence from the Philippines and Kenya suggests that providing savers with deposit collection services increases savings and investment (Ashraf, Karlan and Yin 2006a; Dupas and Robinson 2009). It could be that deposit collection services remove a small cost barrier to making deposits, allowing individuals who might procrastinate to realize their intentions of saving more. However like defaults, the "commitment" provided by deposit collection service is easy to reverse and therefore unlikely to provide assistance to individuals who face serious self control programs. Instead, it could be that deposit collection service brings savings to the top of mind on a regular basis, helping individuals attend to future expenditure opportunities while making current consumption decisions.

\section{REMinders OF OTHER Forms}

Zwane et al (2009) find that taking a baseline survey on aspects of household finance and health increases the subsequent takeup of health insurance products. Relatedly, Stango and Zinman (2010) find that taking a survey that mentions bank overdrafts decreases the subsequent likelihood of paying an overdraft fee. This behavior could be consistent with limited attention consumers. If surveys focus

individual attention on future expenditure opportunities (health expenses and or fees), they could increase individuals' willingness to invest in those opportunities in the current period. 


\section{Experimental Design}

Here we describe the setting, design, and implementation for three field experiments designed to test two theoretical predictions 1) that reminders increase savings and 2) that reminders mentioning a particular planned future expenditure will increase savings more than reminders that do not mention the expenditure. Each design involves individuals responding to a marketing offer to open a goaloriented savings account. Linking back to the model, this implies that at the time of deciding whether to open the account, the individual is thinking about the future expenditure, though he may forget it in the future. In each experiment, after the account is opened, the bank then randomly assigned clients to either receive a reminder or not. Each bank also had its personnel collect some "baseline" data prior to making the product offer. In one of the sites (Philippines), the account includes a commitment feature, i.e., the individual may not withdraw funds until a preset goal is reached. This has potentially important implications for the sample frame, i.e., that only those who see value in commitment to save open the accounts. For these products, the three banks each targeted the working poor and lower middle class.

\section{Experiment 1: First Valley Bank, Western Mindanao, Philippines}

First Valley Bank (FVB), a for-profit bank operating in Western Mindanao, Philippines, worked with us to randomize reminders as part of the rollout of its Gihandom (Dream) Savings product. ${ }^{10}$ Between April and August 2007, bank marketing employees conducted door-to-door marketing visits in rural and small urban areas and offered 10,056 individuals the opportunity to open a Gihandom account. As part of this marketing visit, the bank employee also conducted a brief five to ten minute survey. Bank staff used personal digital accessories (PDAs) for the baseline survey and random assignment to treatments. Of the 10,056 individuals, 2,314 (23\%) opened an account. The reminders treatment was not part of the marketing of the account, and thus the analysis will be conducted only on those who took-up.

\footnotetext{
${ }^{10}$ The bank also randomly assigned people to: a) a low interest rate, high interest rate, or low interest rate $+1.5 \%$ reward for goal attainment; b) whether clients were given offers for an individual account only, a joint account only, or the choice of individual or joint account. Requiring a joint account significantly reduced take-up and lowered savings (but the effect was not statistically significant). Neither the high interest rate nor the reward interest rate had a statistically meaningful impact on take-up or meeting savings goals. We control for these offers in our analysis of the effectiveness of reminders.
} 
Gihandom allows a client to set her own savings goal amount (US\$50 or above) and goal term (from three months to two years). Once the client opens the account with a minimum deposit of US $\$ 2.50$, there is no fixed deposit schedule to fulfill. The client receives a savings lockbox and is encouraged at sign-up to make small deposits on daily basis. When the lockbox is full, the client goes to the bank to deposit the money. The rules of the account differ from the commitment savings product described in Ashraf, Karlan and Yin (2006b) in that money in the account can be withdrawn only if the account reaches the goal amount and the goal term has concluded.

Among clients with a cell phone ( $66 \%$ of those who opened accounts), the bank randomly assigned some clients to receive one "regular" text message reminder to make a deposit each month. Among those assigned to get regular reminders, the bank also randomized whether the message used gain or loss language with respect to "making your dream come true." The text of the reminder messages are provided in Table 1a. ${ }^{11}$ Table 2 reports some validation checks on the integrity of the randomizations. ${ }^{12}$

Clients were also randomly assigned to receive a "late" text message reminder or not, independently of their assignment to receive a regular reminder. The late text reminder was only sent if the client did not make any deposit in a given month. Similar to the regular text message reminders, late text messages reminders were also randomized to gain or loss frame language. If the client was assigned to receive both a regular text reminder and a late text reminder, then client always received either gain frame for both, or loss frame for both. The text of the late reminders is included in Table 1a. Table 2 shows checks on the integrity of the randomization. ${ }^{13}$

\section{EXPERIMENT 2: BANK OF ICA, ICA, PERU}

In Peru, the Government owned bank Caja de Ica worked with us to randomize reminders as part of the rollout of a new commitment savings product called Plan Ahorro ("Saving Plan"). The

\footnotetext{
${ }^{11} \mathrm{~A}$ fourth group was randomly assigned to deposit collection service. The deposit collection was not widely used, and thus the bank stopped providing the service. We include controls for individuals who were originally assigned to receive deposit collection.

${ }^{12}$ In the Philippines, we have income data based on individual reports about their income in the past seven days. A wealth index was constructed from a range of survey variables including income, whether the individual owns a home, water source, roof, and whether they have a shared pipe for water.

${ }^{13}$ The wealth variable in Peru is constructed using the IRIS poverty score card in Peru, where where "wealthy" = above the poverty line.
} 
bank marketed the product on television and radio, and clients signed up over the course of several months. When opening an account, Plan Ahorro clients selected a commitment period (either 6 months or 12 months), a minimum amount to deposit each month, and a goal/account label from 14 pre-established categories (these savings goals appear in Appendix Table 1). Clients were required to make their planned deposit within ten days of each monthly due date in order to meet their commitment. Clients who completed their commitment were rewarded with an annualized interest rate of $8 \%$ per annum rather than the normal $4 \%$ per annum.

As in our other sites, the bank randomly assigned reminders to clients after they signed up for the product. The bank sent letters because low cell phone prevalence made text messages impractical. As in the Philippines, the bank did independent randomizations for "regular" and "late" reminders, which were jointly to a gain or a loss frame. ${ }^{14}$ Table $1 \mathrm{~b}$ shows the text of the different reminder letters.

Each month, the bank sent clients assigned to the regular reminder group a letter seven days before the due date for that month's scheduled deposit. As in the Philippines, clients assigned to the late reminder group got a letter only if they were late (i.e., if they still had not made a deposit three days after their scheduled deposit date). ${ }^{15}$

The bank implemented two additional treatments designed to increase the salience of the client's specific, labeled goal. One treatment randomly assigned some in the reminder group to get a letter that focused on their particular goal (in addition to containing the boilerplate reminder content, see Table 1b). Another treatment independently and randomly assigned the gift clients received upon opening the account: a jigsaw puzzle of their goal, a photo of their goal, or a pen. Those in the jigsaw puzzle group received a piece of the puzzle after each deposit.

\footnotetext{
${ }^{14}$ The bank also randomly assigned clients to receive a message on each month's deposit slip (gain frame vs loss frame; a mention of goal versus no mention of goal, or control). The bank also assigned some individuals to receive a reminder message written by the bank and another group to receive a reminder message written in an individual's own hand. These treatments did not impact the amount that individuals saved.

${ }^{15}$ Clients assigned to receive late reminders were randomly assigned to receive their late reminder if (a) they were late for any scheduled deposit, (b) they were late for any of the first four scheduled deposits, and c) they were late for any of the fifth or later scheduled deposits. These timing treatments had imprecisely estimated and statistically insignificant effects on savings.
} 
Experiment 3: Ecofuturo Bank, Bolivia

In Bolivia, Ecofuturo, a for-profit bank, worked with us to implement a text message reminder program as part of its established, popular commitment savings product Ecoaguinaldo. "Aguinaldo" is the year-end bonus, equal to one month's pay, that employers are required to pay employees in Bolivia. Ecofuturo markets Ecoaguinaldo as a product designed to help its clients, many of whom are self-employed, save up all year for their own year-end payout. The product was marketed for three months between January and March on television and radio. Clients were required to sign up for the product by March 31, and made savings deposits from the time of their enrollment until the December payout date.

At sign-up, clients chose a monthly minimum deposit amount (with a floor of US\$1.41), and the bank offered a set of incentives for making the pledged, minimum monthly deposits. Clients making all of their pledged monthly deposits received a bonus interest rate of $6 \%$ for their first ten months following enrollment in the program (compared to a regular interest rate of $3 \%$ ) as well as free life and accident insurance. ${ }^{16}$ Clients missing one deposit, or withdrawing money before the payout date, forfeited the higher interest rate and had their insurance policies canceled.

Clients with a cell phone were randomly assigned to receive text message reminders or not. ${ }^{17}$ Unlike the other sites, clients did not receive late reminders. The bank began sending reminders to a randomly selected subset of the reminder group in May 2008, and continued with the entire sample from June 2008 through November 2008. In the first two months of the program following May 2008 all of the reminder clients received text message reminders, regardless of whether they had already made a deposit. In the remaining four months of the program, only clients who had not yet made a deposit received a text message reminder. ${ }^{18}$

Clients in the treatment group were further divided into one of four reminder content subtreatments. Some messages mentioned the insurance incentive, while others did not. Reminders

\footnotetext{
${ }^{16}$ Ecofuturo paid the monthly premiums of $\$ 0.13$ and $\$ 0.32$ on policies that paid $\$ 214$ in the event of death and $\$ 285$ in the event of debilitating injury.

${ }^{17}$ Some individuals had multiple accounts. Our analysis focuses on the total saved in all accounts. We include controls for the number of accounts that individuals have.

${ }^{18}$ In our analysis, these clients are still considered to be in the text message treatment group since they received messages in the first months of the program.
} 
were also randomized to gain or loss frames. Table 1c shows the different scripts of the reminders.

\section{Results}

\section{Overall Effect of Reminders on Saving}

One of the two key testable predictions of our model is that reminders will increase savings. Our primary, and simplest, test of this prediction is to use data from all three experiments to identify the effect of getting any reminder.

$$
Y_{i}=\alpha+\beta R_{i}+\gamma Z_{i}+\varepsilon_{i}
$$

We measure $Y$, savings by client $i$, two different ways: the log of $(1+$ the total amount saved in the bank account by the end of the commitment period), ${ }^{19}$ or an indicator for whether the client saved her targeted amount by the end of commitment period. $R$ is an indicator that equals 1 if the bank randomly assigned the client to receive any reminder. $Z$ is a vector of randomization conditions, other treatment assignments, and country fixed effects. We also provide specifications that show robustness to including $X$, a vector of the client's baseline characteristics. We report OLS estimates in the main tables; the results are robust to using probit for the binary measure of saving (see Appendix Tables 2a and 2b).

Table 3 Panel A presents estimates of equation (2). Clients who received monthly reminders saved $6 \%$ more than individuals who did not, with a p-value of 0.079 or 0.065 , depending on whether we include client baseline covariates (Columns 1 and 2). Reminders also made clients 3 percentage points more likely to save their targeted amount ("reach savings goal" below) by the end of the commitment period. Table 3 Panel B presents results separately for each experiment. We do not find any evidence that reminders have significantly different effects across settings, although these estimates are a bit imprecise: the confidence intervals do not rule out economically meaningful differences across the three settings.

\section{The Salience of Specific Expenditures}

Our model also predicts that reminders which are highly associated with a particular future

\footnotetext{
${ }^{19} 2,592$ clients had made no deposits by the end of the study.
} 
lumpy expenditure will increase savings. We can test this prediction in Peru, our only setting where clients labeled their savings account with a specific future expenditure.

Table 4 Panel A shows support for this prediction. Reminders that mentioned the specific expenditure increased savings by an estimated $16 \%$ relative to no reminder, while reminders that did not mention the specific expenditure had no effect (Column 1). The difference between these two reminder coefficients is significant. In contrast, we do not find significant effects, or a significant difference between the effects, of the two types of reminders on goal attainment (Column 2).

\section{Salience, Mental Accounting, and Timing}

Table 4 Panel B sheds some further light on the relationship between mental accounting (in the form of the specific expenditure clients use to label their accounts in Peru), limited attention, and the timing of shocks to attention. Recall that, in addition to reminders, the bank in Peru also randomly and independently assigned clients to a second treatment that was designed to increase the salience of the client's specific future expenditure.Clients in the control group received a pen from the bank, at account opening. Clients in the treatment group were randomly received either a photograph of the future expenditure they used to label the account, or a piece of a jigsaw puzzle depicting the future expenditure (an example of a photograph a goal is included in Appendix Figure 2). ${ }^{20}$ Neither of these treatments significantly affected savings. Furthermore, these treatments were significantly less likely to increase savings than the expenditure specific reminders. ${ }^{21}$

Note that the timing of these treatments differs from the reminders. Clients got photos at account opening. Clients got a puzzle piece after making a deposit. Clients got reminders before making a deposit.

The nature of the treatments differs as well. The photo and puzzles reinforce the client's goal (the specific expenditure), but not a means toward achieving a goal (making the next deposit). The reminders are focused on the means (making a deposit), and the most effective reminders also

\footnotetext{
${ }^{20}$ Most pictures were self explanatory. When individuals were saving for an "emergency," the picture of their goal was a hospital emergency room. For individuals saving for the goal "other," the picture of their goal was the logo of the "Plan Ahorro" savings account.

${ }^{21}$ The comparison of expenditure specific reminder to puzzle has F-statistic $=8.10$ and the comparison of the expenditure specific reminder and photo treatment has F-statistic $=10.27$.
} 
mention the goal.

The results here suggest that both the timing and content can impact the effectiveness of shocks to attention. We discuss some implications for further research in the conclusion.

\section{Alternative Explanations}

Perhaps reminders impact saving because they are a signal from the bank that saving is important, or that the bank values the client's relationship? The regular communication in the form of a reminder may also have increased clients' trust of the bank. These alternatives to limited attention could explain the main effect of reminders, but not the differential impact of reminders that mention the client's goal. Nor do these alternatives explain why (well-timed) reminders are more effective than gifts like the photo, puzzle, or pen (although naturally these alternative treatments may simply have been ineffective, i.e., they did not successfully act as a signal or generate higher levels of trust).

Another explanation for the effectiveness of reminders would be a two part argument: individuals are not merely hyperbolic or consistent as is traditionally modeled (Laibson 1997; O'Donoghue and Rabin 1999), but stochastically hyperbolic, and that reminders lower the probability of being hyperbolic in a given time period. The mechanism is not so different from our model here, in that the reminder "works" by focusing attention on the future, in the case of attention by simply incorporating the future expenditure into the current consumption and savings decision, and in the case of hyperbolic preference by changing the discount rate which drives the choice between consumption and savings.

\section{Heterogeneity in the Effectiveness of Reminders}

As shown in Section II, our model also predicts that reminders will be especially effective on individuals who appear time-inconsistent, if time-inconsistency is due to the interaction of limited attention and liquidity constraints rather than time preferences that are present-biased. Our entire sample is plausibly credit constrained, so we test this prediction by simply estimating the interaction between reminders and a measure of time-inconsistency obtained in the Philippines baseline survey. Table 2 shows that $16 \%$ of the Philippines sample made time-inconsistent choices when presented with the hypothetical: "Would you prefer to receive P200 ( $~=\$ 4$ USD) guaranteed today, or P300 
$\left({ }^{\sim}=\$ 6\right.$ USD) guaranteed in 1 month?" and "Would you prefer to receive P200 guaranteed in 6 months, or P300 guaranteed in 7 months?"

Table 5 shows some support for the prediction that reminders will be more effective on timeinconsistent individuals. This holds for savings balances (a $47 \%$ increase, with a p-value of 0.07 ), and we also find a large and positive point estimate on savings goal attainment ( 7 percentage points, or $35 \%$ ), although that treatment effect is not significantly different from zero.

\section{Other AcCount features}

Appendix Table 3 presents results from other treatments with weaker links to the theory. Panel A shows that reminders in Bolivia increased savings when they mentioned the account's financial incentive (along with the "year-end payout" used to frame the account). Reminders that do not include this financial incentive do not significantly impact savings. We do not find strong evidence of differential effects of loss vs. gain-framed reminder messages (Panel B), of late vs. regular reminders (Panel C), or of client-written vs. bank-written reminders (Panel D).

\section{Cost Effectiveness of Reminders}

The variable cost of sending direct mail reminders is nontrivial (almost a dollar in the Peru context). Given our estimated treatment effect (a $6 \%$ increase in bank balances) and the small average balances ( $\$ 100$ or less), mailing reminders is not cost-effective for banks under reasonable assumptions about rates of return on deposited funds. Indeed the one bank here that experimented with mailing reminders discontinued them after the study. However, sending reminders by text message has near zero marginal cost. And indeed Ecofuturo in Bolivia has continued sending the reminders. Direct mail costs and the recent emergence of low-cost text messaging may help explain why most banks have not (yet) offered reminders to save.

\section{Conclusion}

We develop and test a model of savings and consumption behavior when individuals have limited attention. Our model predicts that individuals will undersave when they are inattentive to some future expenditures. The model generates several phenomena that overlap with other behavioral models, including high levels of debt relative to savings, mental accounting, and sticky defaults. Our 
model also makes the unique predictions that reminders to save will increase savings, that reminders mentioning a particular future expenditure will be especially effective, and that reminders will be especially effective on time-inconsistent individuals (given, as we show, that time-inconsistency can be driven by limited attention and credit constraints rather time preference reversals per se). We find support for these predictions in field experiments with three banks in the Philippines. These findings raise several issues for further research.

One key question going forward is the relationship between present-biased attention and presentbiased preferences. Are both biases prevalent, and correlated with each other? Or does one dominate decision making (in certain domains)? Our results open up the possibility that phenomena attributed to unstable time preference may in fact be due to limited attention, but more work is needed to address this possibility rigorously.

A closely related issue is measuring a broader set of outcomes that might be affected by "treatments" for limited attention. If limited attention takes particular forms, or if consumers have additional behavioral biases, then attention-getting treatments could have countervailing and even perverse effects. Reminders from one bank may crowd-out savings in other instruments, or even induce (expensive) borrowing to offset lost consumption, thereby reducing savings on net.

Understanding the market for attention is critical. For example, only one of the banks that implemented reminders in this study has continued reminding its clients to save. Might the market under-supply reminders, particularly if consumers are naive about their limited attention? Do lenders exploit attentional failures by providing financing "on-demand," that is tied to specific expenditures (as is common in durables financing), and comes with built-in reminders (e.g., required monthly payments)?

Deriving the optimal content and timing of attention treatments also offers rich possibilities for future work. Our results hint that reminders are most effective when they focus on both a particular future goal set by the client (e.g., a future expenditure to be purchased with a targeted savings amount), and on the means toward achieving that goal (making the next deposit). But our results suggests that the relationships between ends, means, and attention are complex; e.g., in the one site 
where the bank (and not the client) labeled the account with a homogeneous goal- the year-end payout in Bolivia- reminders were only effective when they mentioned financial incentives for goal attainment.

We also speculate that the frequency and source of attention shocks plays an important role. Attention may interact with habit formation; e.g., if reminders to save induce consumers to adopt pro-savings routines. Conversely, some consumers may eventually "tune out" repeated reminders.

These dynamics suggest that reminders or other attention shocks may be most (cost-)effective when they focus on inducing a one-time change with "sticky" consequences (e.g., 401k enrollment, fertilizer prepayment, or automatic payment of annual car registration fees). Ultimately, the welfare implications of limited attention presumably depend not only on how a consumer responds to a given attention shock, but on how shocks are generated (endogenously) and interact. It should be fruitful to build bridges between models like ours, and models where firms (and other agents) compete for consumer attention. 


\section{Appendix}

\section{Formal Definition of Salience}

The probability that individuals attend to future expenditures may depend on events that occur in the current period. For example, a reminder to save for school fees in each period will make people more likely to attend to the opportunity to pay for school fees when they occur. Other events may have a weaker association with future opportunities. For example, the event of meeting the parents of your daughter's fiance may or may not be associated with the future opportunity of financing your daughter's wedding.

In order to consider the role of events, we assume that in each period $t$, there is a set of events that may occur:

$$
\varepsilon_{t}=\left\{e_{1}^{t}, \ldots, e_{K}^{t}\right\}
$$

Events occurring in period $t$ have some association with opportunities that occur in the future (periods $\tau>t$ ). The strength of the association between an event in the current period $t$ and an opportunity in a future period $\tau$ is denoted by the parameter $a_{k \tau} \geq 0$. The probability of attention in period $t$ an opportunity that will occur in period $\tau$ is

$$
\theta_{\tau}^{t}=F\left(m+\sum_{k=1}^{K} a_{k \tau} e_{k}^{t}\right)
$$

where $m$ represents a baseline probability of attention to future opportunities and events associated with future opportunities increase the probability of attending to future opportunities. $F$ represents a cumulative density function such that $0<=F(x)<1$ and $F$ is increasing in $x$. We can use this framework of events and associations to consider a more formal definition of salience. ${ }^{22}$

The salience of a future expenditure in the current period is the average association of all current events with that future opportunity. The salience of an event occurring in $\tau$ to an individual in

\footnotetext{
${ }^{22}$ In our model, events occurring in the present can increase the salience of future expenditure opportunities in a way that is related to the ability of current events to increase recall of the past as proposed by Mullainathan's (1998) model of memory.
} 
period $t$ can be represented as

$$
S_{\tau}^{t}=\left(\sum_{k=1}^{K} a_{k \tau} e_{k}^{t}\right) / K
$$

Individuals are more likely to attend to future opportunities that are highly associated with current events or that are associated with many events in the present. In turn, individuals are more likely to attend to opportunities in the future that have high salience today. That is because increasing the salience of a future opportunity in the current period will increase the probability of attention to that opportunity today. Since the average number of expenditures an individual attends to when planning for the future increases in $\theta$ (as can be seen in equation (1)), expected savings will increase as the salience of future opportunities increases. 


\section{REFERENCES}

[1] Armstrong, A., Watson, A. Makredes, M., Frangos, J., Kimball, A., and Kvedar, J. (2009), "Text-Message Reminders to Improve Sunscreen Use: A Randomized, Controlled Trial Using Electronic Monitoring," Arch Dermatol, 145(11), 1230-1236.

[2] Ananth, B., Karlan, D., Mullainathan, S. (2007), "Microentrepreneurs and Their Money: Three Anomalies," Working paper.

[3] Ashraf, N., D. Karlan, Yin, W. (2006a), "Deposit Collectors," Advances in Economic Analysis \& Policy, 6 Article 5.

[4] Ashraf, N., D. Karlan, Yin, W. (2006b), "Tying Odysseus to the Mast: Evidence from a Commitment Savings Product in the Philippines," Quarterly Journal of Economics 121(2), 673-697.

[5] Ball, L., Mankiw, G. and Reis, R. (2005), "Monetary Policy for Inattentive Economies," Journal of Monetary Economics, 52(4), 703-725.

[6] Banerjee, A. and Mullainathan, S. (2008), "Limited Attention and Income Distribution," American Economic Review, 489-93.

[7] Banerjee, A., Mullainathan, S. (2009), "The Shape of Temptation: Implications for the Economic Lives of the Poor" working paper.

[8] Benartzi, S. and Thaler, R. (2004), "Save More Tomorrow (TM): Using Behavioral Economics to Increase Employee Saving," Journal of Political Economy, 112(S1), S164-S187.

[9] Beshears, J., Choi, J., Laibson D., and Madrian, B. (2006), "The Importance of Default Options for Retirement Saving Outcomes: Evidence from the United States," NBER Chapters, in: Social Security Policy in a Changing Environment, National Bureau of Economic Research, Inc.

[10] Buehler, R., Griffin, D., and Ross, M. (2002), "Inside the Planning Fallacy: The Causes and Consequences of Optimistic Time Predictions," In T. Gilovich, D. Griffin, and D. Kahneman (Eds.), Heuristics and Biases: The Psychology of Intuitive Judgment, 250-270. Cambridge, UK: Cambridge University Press. 
[11] Chetty, R., Looney, A. and Kroft, K. (2009), "Salience and Taxation: Theory and Evidence," American Economic Review, 99(4), 1145-77.

[12] Choi, J., D. Laibson, B. Madrian and A. Metrick (2004), "For Better or For Worse: Default Effects and 401(k) Savings Behavior," Perspectives in the Economics of Aging, D. Wise. Chicago, University of Chicago Press, 81-121.

[13] Choi, J., Laibson, D., Madrian, B. , Metrick, A. (2005), "Saving for Retirement on the Path of Least Resistance," in E. McCaffrey and J. Slemrod, eds., Behavioral Public Finance, 2005.

[14] DellaVigna, S. (2009), "Psychology and Economics: Evidence from The Field," Journal of Economic Literature, 47, 315-372.

[15] Duflo, E. Kremer, M., Robinson, J. , (2009), "Nudging Farmers to Use Fertilizer: Evidence from Kenya," Working paper.

[16] Dupas, P. , Robinson, J. (2009), "Savings Constraints and Microenterprise Development: Evidence from a Field Experiment in Kenya," NBER Working Papers 14693, National Bureau of Economic Research, Inc.

[17] Fudenberg, D. and Levine, D. (2006), "A Dual Self Model of Impulse Control," American Economic Review, 96(5), 1449-1476.

[18] Gabaix, X. and Laibson, D. (2006), "Shrouded Attributes, Consumer Myopia, and Information Suppression in Competitive Markets," The Quarterly Journal of Economics,121(2), 505-540.

[19] Gul, F. and Pesendorfer, W. (2004), "Self-Control and the Theory of Consumption," Econometrica, 72(1), 119-158.

[20] Krishna S., Austin Boren S., Balas E., (2009), "Healthcare via Cell Phones: A Systematic Review," Telemedicine and e-Health, 15(3), 231-40.

[21] Laibson, D. (1997), "Golden Eggs and Hyperbolic Discounting," Quarterly Journal of Economics, 112, 443-477. 
[22] Laibson, D. (2001), "A Cue-Theory of Consumption," Quarterly Journal of Economics, 116, 81-119.

[23] Laibson, D., Repetto, A., Tobacman, J. (2007), "Estimating Discount Functions with Consumption Choices over the Lifecycle," NBER Working Papers 13314.

[24] Macharia W., Leon G., Rowe B., Stephenson B., and Haynes R. (1992), "An Overview of Interventions to Improve Compliance with Appointment Keeping for Medical Services," Journal of the American Medical Association, 267, 1813-1817.

[25] Madrian, B. and Shea, D. (2001), "The Power of Suggestion: Inertia in 401(k) Participation and Savings Behavior," The Quarterly Journal of Economics,116(4), 1149-1187.

[26] Mankiw, G. and Reis, R. (2002), "Sticky Information versus Sticky Prices: A Proposal to Replace the New Keynesian Phillips Curve," Quarterly Journal of Economics, 117(4) 12951328.

[27] Meier, S., and Sprenger, C. (2009), "Discounting and Defaulting: Evidence from Time Preference Experiments and Administrative Credit Data," working paper.

[28] Miloh T., Annunziato R., Arnon R., Warshaw, J., Parkar, S., Suchy, F., Iyer, K. and Kerkar, N. (2009), "Improved Adherence and Outcomes for Pediatric Liver Transplant Recipients by Using Text Messaging," Pediatrics, 124(5), 844-50.

[29] Mullainathan, S. (2002), "A Memory-Based Model Of Bounded Rationality," The Quarterly Journal of Economics, 117(3), 735-774.

[30] O'Donoghue, T. and Rabin, M. (1999), "Doing it Now or Doing it Later," American Economic Review, 89(1), 103-124.

[31] Reis, R. (2006), "Inattentive Consumers," Journal of Monetary Economics, 53(8), 1761-1800.

[32] Schwartzstein, J. (2009), "Selective Attention and Learning," Unpublished. 
[33] Sims, Christopher A. (1998), "Stickiness," Carnegie-Rochester Conference Series on Public Policy, 49 317-356.

[34] Sims, Christopher A. (2003), "Implications of Rational Inattention," Journal of Monetary Economics, 50(3), 665-690.

[35] van Dulmen, S., Sluijs, E., van Dijk, L., de Ridder, D., Heerdink, R. and Bensing, J. (2007), "Patient Adherence to Medical Treatment: A Review of Reviews," BMC Health Services Research, $7: 55$

[36] Stango, V. and Zinman, J. (2010), "Limited and Varying Consumer Attention: Evidence from Shocks to the Salience of Penalty Fees," working paper.

[37] Thaler, R. (1990), "Saving, Fungibility and Mental Accounts," Journal of Economic Perspectives, 4, 193-205.

[38] Zwane, A., Zinman, J., Van Dusen, E. Pariente, W., Null, C., Miguel, E., Kremer, M., Karlan, D., Hornbeck, R., Giné, X., Duflo, E., Devoto, F., Crepon, B., and Banerjee, A. (2009), "The Risk of Asking: Being Surveyed Can Affect Later Behavior," working paper. 
$80003^{8} \cos ^{8}$

89

\section{HAVE TROUBLE REMEMBERING?}

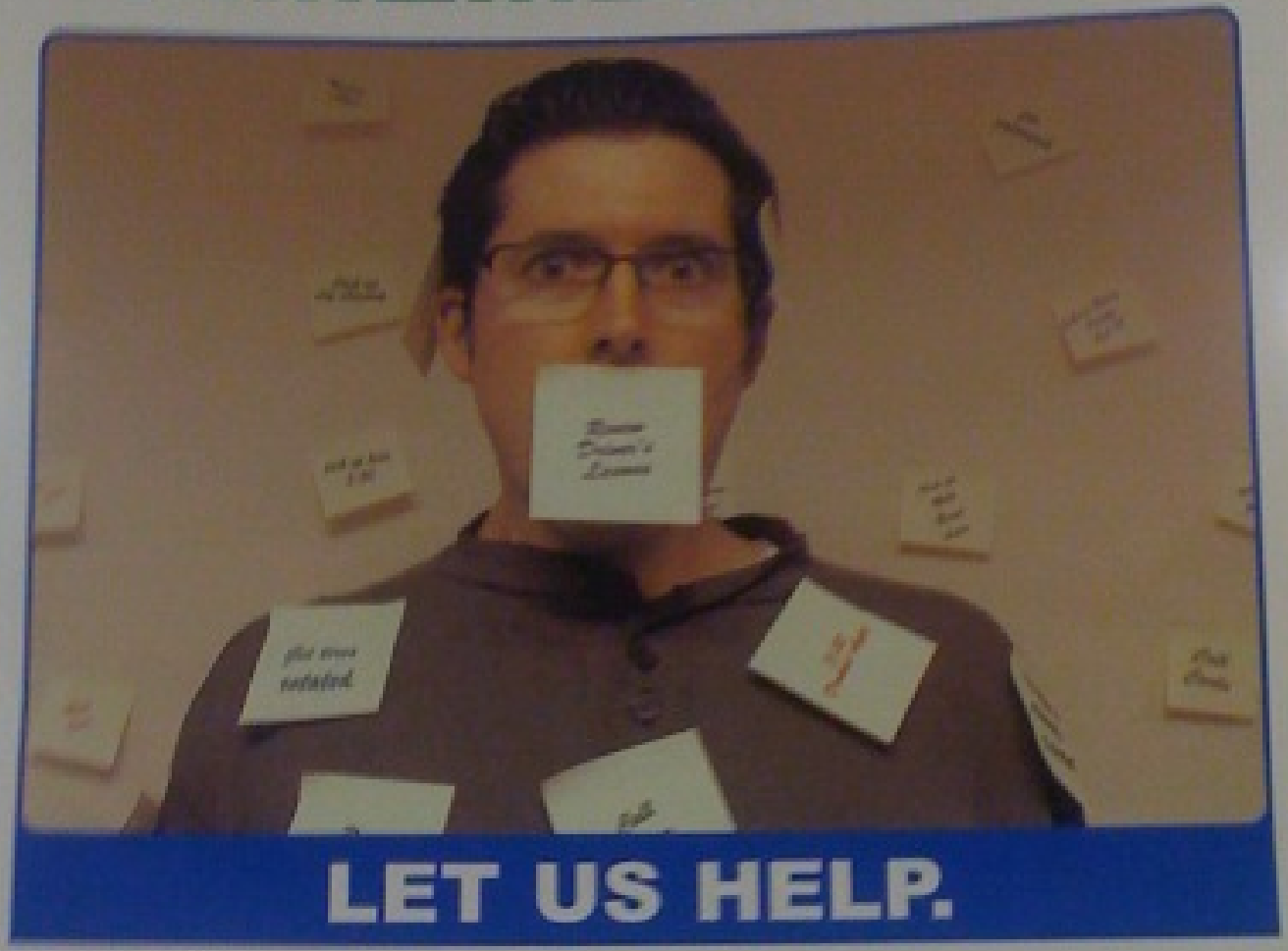

Sign up for the

FREE RMV
REMINDER
SERVICE

and receive reminders by email, phone, or text.

wwW.mass.gov/rmv

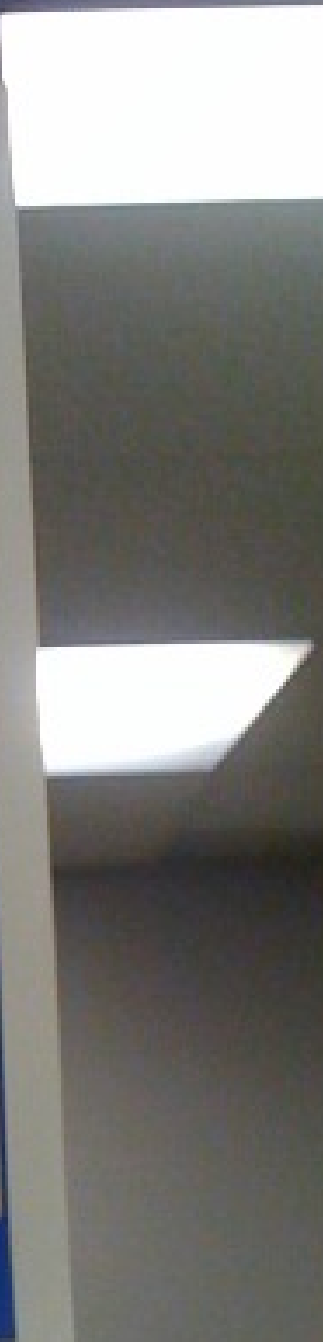


Appendix Figure 2: Example of Photograph of Goal

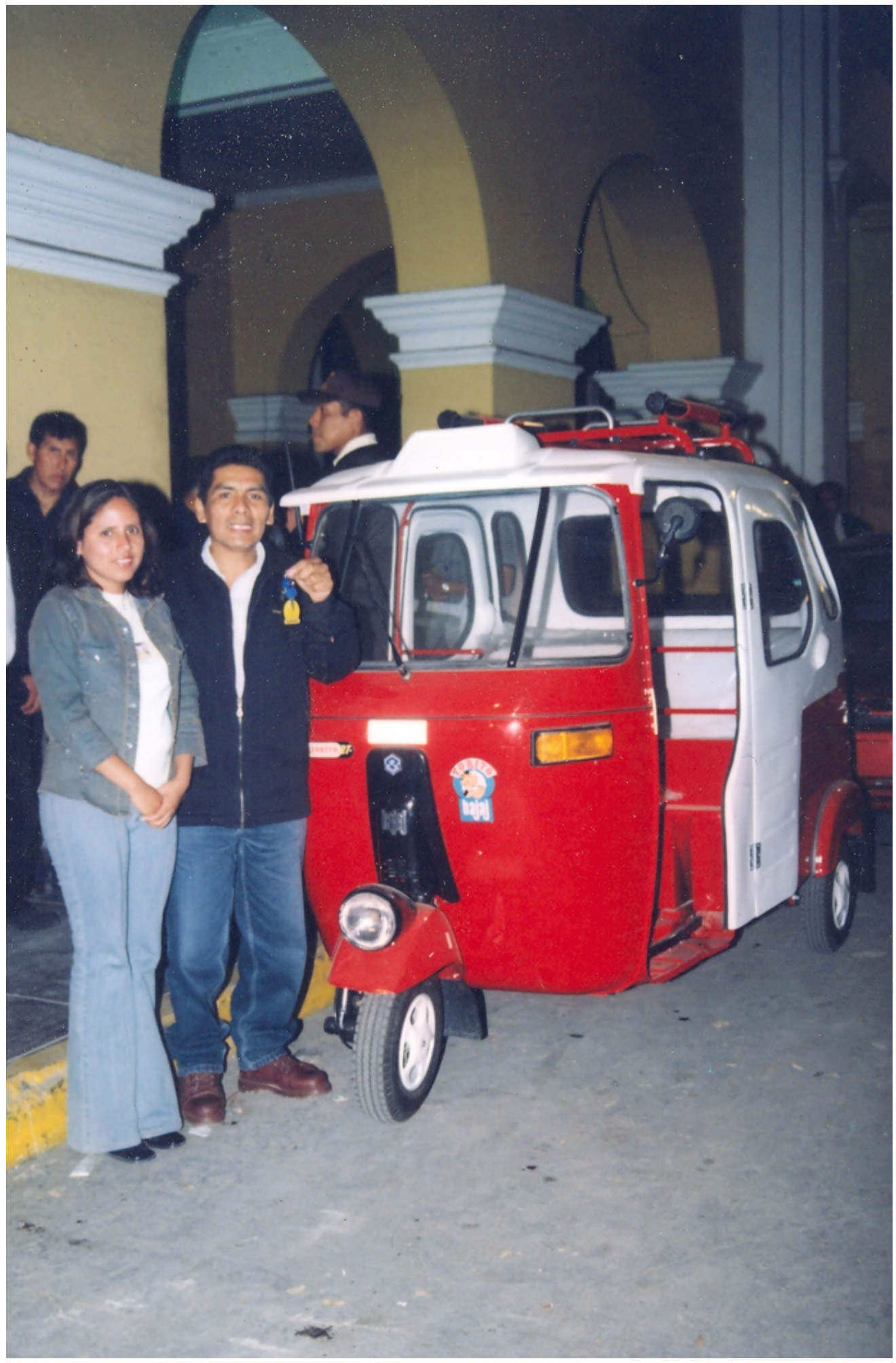


Table 1a: Message Treatments

\begin{tabular}{|c|c|c|}
\hline \multicolumn{3}{|r|}{ Philippines } \\
\hline Timing & Frame & Message \\
\hline \multirow{2}{*}{ Regular } & Gain & $\begin{array}{l}\text { Frequent deposit into the Gihandom Savings account will } \\
\text { make your dream come true. A reminder from 1st Valley } \\
\text { Bank. }\end{array}$ \\
\hline & Loss & $\begin{array}{l}\text { If you don't frequently deposit into the Gihandom Savings } \\
\text { account, your dream will not come true. A reminder from 1st } \\
\text { Valley Bank }\end{array}$ \\
\hline \multirow{2}{*}{ Late } & Gain & $\begin{array}{l}\text { You didn't deposit in the 1st Valley Gihandom account for } \\
30 \text { days. Don't forget to deposit, so you can reach your } \\
\text { savings goal, make your dream come true! }\end{array}$ \\
\hline & Loss & $\begin{array}{l}\text { You didn't deposit in the 1st Valley Gihandom account for } \\
30 \text { days. If you forget to deposit, you cannot reach your } \\
\text { savings goal and make your dream come true. }\end{array}$ \\
\hline
\end{tabular}




\begin{tabular}{|c|c|c|c|c|}
\hline \multicolumn{5}{|c|}{ Peru } \\
\hline Timing & Message & Focus & Frame & Message \\
\hline \multirow{4}{*}{ Regular } & \multirow{4}{*}{$\begin{array}{l}\text { We would like to } \\
\text { remind you that your } \\
\text { next Plan Ahorro } \\
\text { deposit should be } \\
\text { made on [Date]. }\end{array}$} & \multirow{2}{*}{$\begin{array}{l}\text { Standard } \\
\text { Reminder }\end{array}$} & Gain & $\begin{array}{l}\text { Regular + If you make all of } \\
\text { your deposits, you will receive a } \\
\text { total of [Amount] in additional } \\
\text { interest rate incentive! }\end{array}$ \\
\hline & & & Loss & $\begin{array}{l}\text { Regular + If you miss a } \\
\text { payment, you will lose a total of } \\
\text { [Amount] in additional interest } \\
\text { rate incentive! }\end{array}$ \\
\hline & & \multirow{2}{*}{$\begin{array}{l}\text { Specific } \\
\text { Expenditure } \\
\text { Reminder }\end{array}$} & Gain & $\begin{array}{l}\text { Regular + If you make all of } \\
\text { your deposits, you will receive a } \\
\text { total of [Amount] in additional } \\
\text { interest rate incentive that you } \\
\text { will be able to use to reach your } \\
\text { savings goal of [Goal]! }\end{array}$ \\
\hline & & & Loss & $\begin{array}{l}\text { Regular + If you miss a } \\
\text { payment, you will lose a total of } \\
\text { [Amount] in additional interest } \\
\text { rate incentive that you will be } \\
\text { able to use to reach your savings } \\
\text { goal of [Goal]! }\end{array}$ \\
\hline \multirow{4}{*}{ Late } & \multirow{4}{*}{$\begin{array}{l}\text { We would like to } \\
\text { remind you that your } \\
\text { Plan Ahorro deposit } \\
\text { should have be made } \\
\text { on [Date]. If you wish } \\
\text { to continue in Plan } \\
\text { Ahorro you should } \\
\text { make your deposit as } \\
\text { soon as possible. }\end{array}$} & \multirow{2}{*}{$\begin{array}{l}\text { Standard } \\
\text { Reminder }\end{array}$} & Gain & $\begin{array}{l}\text { Late + If you make all of your } \\
\text { deposits, you will receive a total } \\
\text { of [Amount] in additional } \\
\text { interest rate incentive! }\end{array}$ \\
\hline & & & Loss & $\begin{array}{l}\text { Late + If you miss a payment, } \\
\text { you will lose a total of [Amount] } \\
\text { in additional interest rate } \\
\text { incentive! }\end{array}$ \\
\hline & & \multirow{2}{*}{$\begin{array}{l}\text { Specific } \\
\text { Expenditure } \\
\text { Reminder }\end{array}$} & Gain & $\begin{array}{l}\text { Late + If you make all of your } \\
\text { deposits, you will receive a total } \\
\text { of [Amount] in additional } \\
\text { interest rate incentive that you } \\
\text { will be able to use to reach your } \\
\text { savings goal of [Goal]! }\end{array}$ \\
\hline & & & Loss & $\begin{array}{l}\text { Late + If you miss a payment, } \\
\text { you will lose a total of [Amount] } \\
\text { in additional interest rate } \\
\text { incentive that you will be able to } \\
\text { use to reach your savings goal of } \\
\text { [Goal]! }\end{array}$ \\
\hline
\end{tabular}




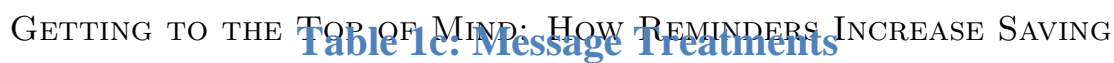

\begin{tabular}{|c|c|c|}
\hline \multicolumn{3}{|r|}{ Bolivia } \\
\hline Focus & Frame & Message \\
\hline \multirow[b]{2}{*}{ Incentive Reminder } & Gain & $\begin{array}{l}\text { Ecofuturo reminds you: Maintain your Ecoaguinaldo life } \\
\text { insurance! Don’t forget your deposit this month! You will } \\
\text { keep your insurance by making all of your deposits on time. }\end{array}$ \\
\hline & Loss & $\begin{array}{l}\text { Ecofuturo reminds you: Don’t lose your Ecoaguinaldo life } \\
\text { insurance! Don't forget your deposit this month! You will } \\
\text { lose your insurance if you don’t make all your deposits on } \\
\text { time. }\end{array}$ \\
\hline \multirow[b]{2}{*}{ Reminder } & Gain & $\begin{array}{l}\text { Ecofuturo reminds you: Your Ecoaguinaldo is within reach! } \\
\text { Don't forget your deposit this month! You will be one step } \\
\text { closer to your savings goal. }\end{array}$ \\
\hline & Loss & $\begin{array}{l}\text { Ecofuturo reminds you: Don't fail to reach your } \\
\text { Ecoaguinaldo! Don't forget you deposit this month! If you } \\
\text { don’t make your deposit you increase the chance of not } \\
\text { reaching your savings goal. }\end{array}$ \\
\hline
\end{tabular}




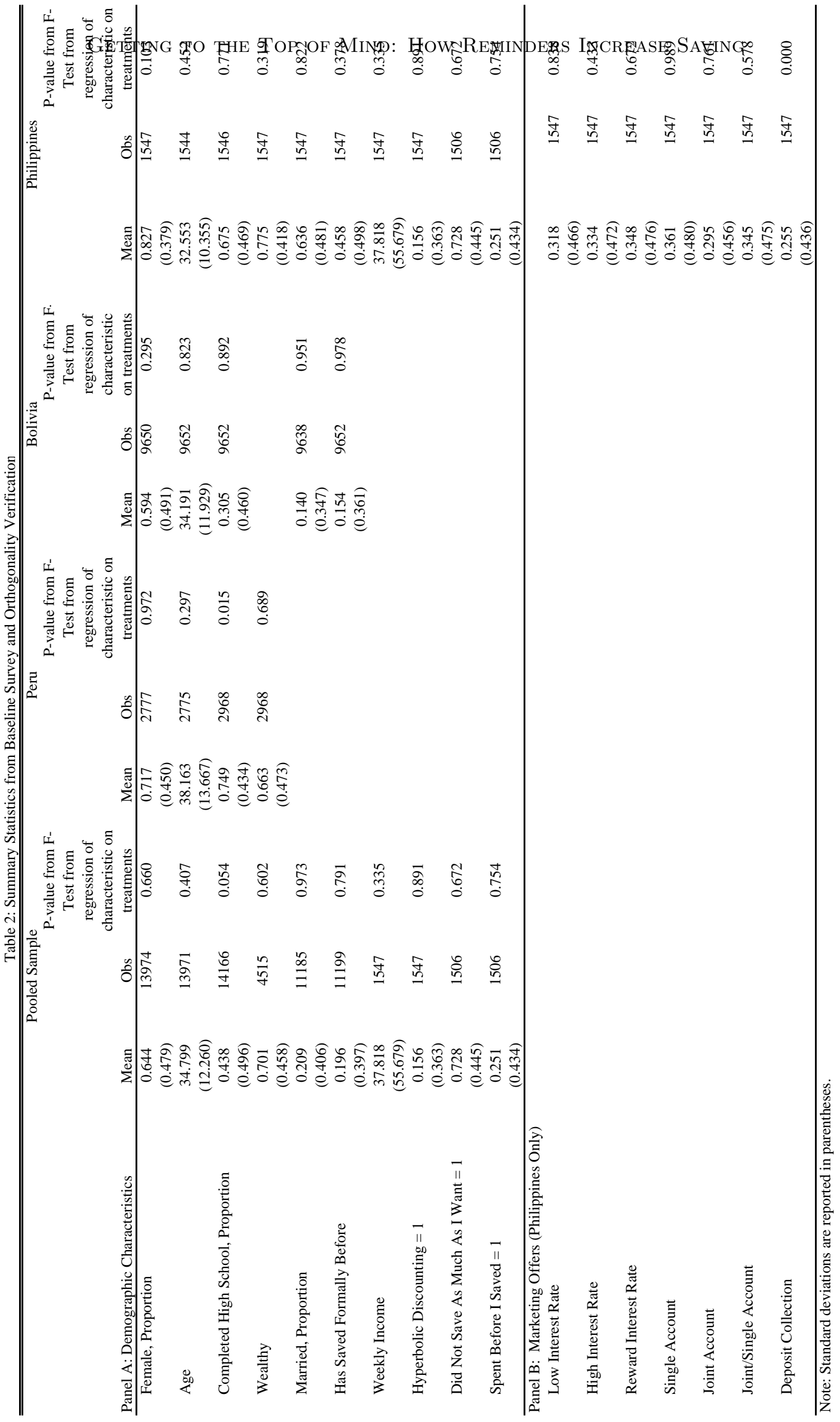




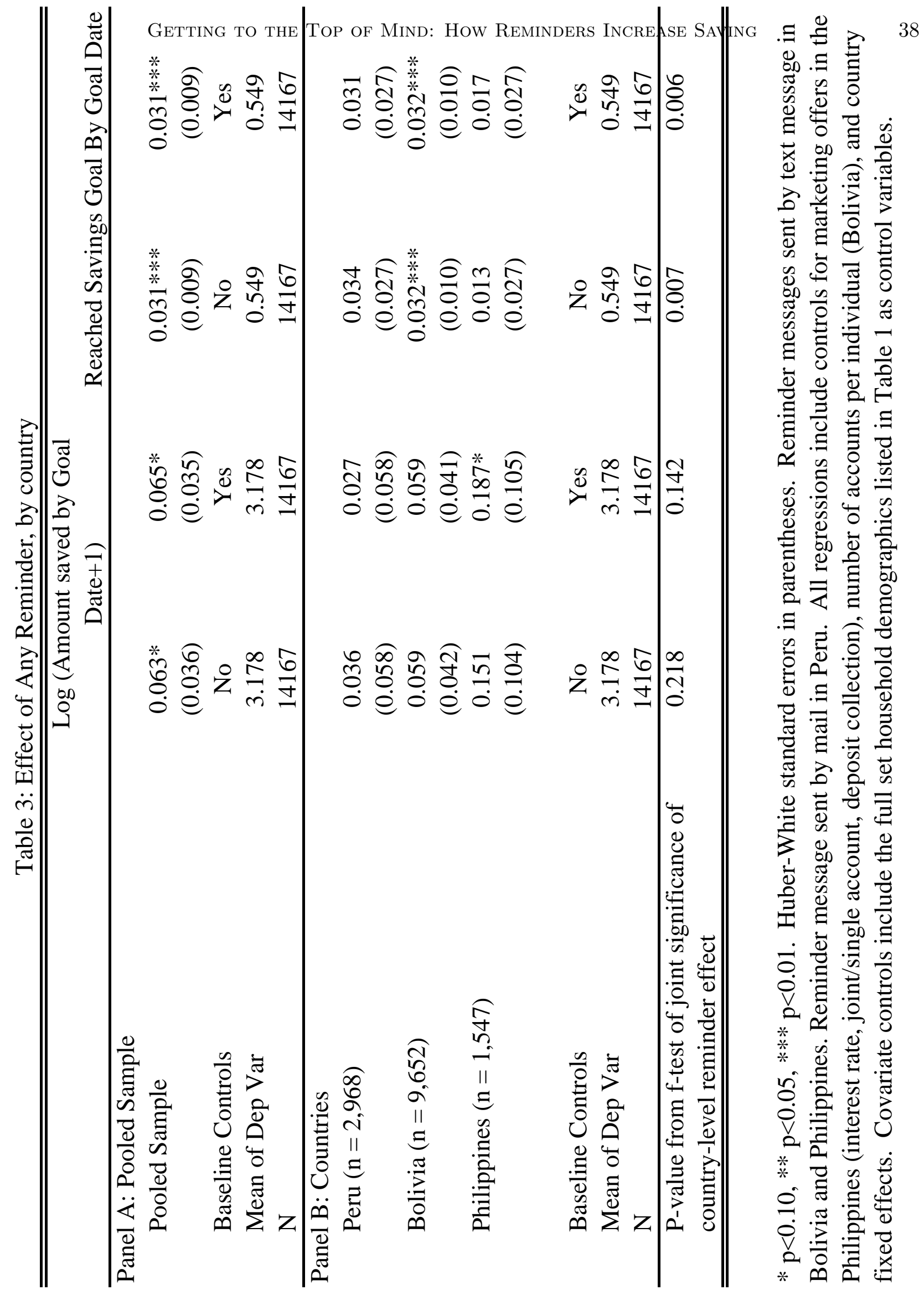


Table 4: Focus on Specific Expenditures (Peru Sample Only)

\begin{tabular}{|c|c|c|c|c|}
\hline \multirow[b]{2}{*}{ Panel A: Specific Expenditure Focused } & \multicolumn{2}{|c|}{ "Log (Amount saved by Goal Date+1) } & \multicolumn{2}{|c|}{ Reached Savings Goal By Goal Date } \\
\hline & & & & \\
\hline Standard Reminder & $\begin{array}{c}-0.007 \\
(0.059)\end{array}$ & $\begin{array}{l}-0.008 \\
(0.059)\end{array}$ & $\begin{array}{c}0.028 \\
(0.027)\end{array}$ & $\begin{array}{c}0.027 \\
(0.027)\end{array}$ \\
\hline Specific Expenditure Focused Reminder & $\begin{array}{c}0.155^{* * *} \\
(0.041)\end{array}$ & $\begin{array}{c}0.153^{* * *} \\
(0.041)\end{array}$ & $\begin{array}{c}0.024 \\
(0.020)\end{array}$ & $\begin{array}{c}0.024 \\
(0.020)\end{array}$ \\
\hline Baseline Controls & No & Yes & No & Yes \\
\hline Mean of Dependent Variable & 4.076 & 4.076 & 0.679 & 0.679 \\
\hline $\mathrm{N}$ & 2968 & 2968 & 2968 & 2968 \\
\hline \multicolumn{5}{|c|}{ Panel B: Effect of Puzzle intervention and Photo Intervention } \\
\hline Puzzle of Goal & $\begin{array}{l}-0.018 \\
(0.042)\end{array}$ & $\begin{array}{l}-0.013 \\
(0.042)\end{array}$ & $\begin{array}{c}0.021 \\
(0.021)\end{array}$ & $\begin{array}{c}0.019 \\
(0.021)\end{array}$ \\
\hline Photo of Goal & $\begin{array}{c}-0.043 \\
(0.046)\end{array}$ & $\begin{array}{l}-0.040 \\
(0.046)\end{array}$ & $\begin{array}{c}0.003 \\
(0.022)\end{array}$ & $\begin{array}{c}0.001 \\
(0.022)\end{array}$ \\
\hline Baseline Controls & No & Yes & No & Yes \\
\hline Mean of Dependent Variable & 4.076 & 4.076 & 0.679 & 0.679 \\
\hline $\mathrm{N}$ & 2968 & 2968 & 2968 & 2968 \\
\hline
\end{tabular}

Table 5: Time Inconsistency (Philippines Sample Only)

\begin{tabular}{|c|c|c|c|c|c|c|c|c|}
\hline \multirow[b]{2}{*}{ Panel A: Time Inconsistency } & \multicolumn{4}{|c|}{ Log (Amount saved by Goal Date +1 ) } & \multicolumn{4}{|c|}{ Reached Savings Goal By Goal Date } \\
\hline & & & & & & & & \\
\hline Any Reminder Message & $\begin{array}{c}0.151 \\
(0.104)\end{array}$ & $\begin{array}{c}0.087 \\
(0.113)\end{array}$ & $\begin{array}{l}0.180^{*} \\
(0.106)\end{array}$ & $\begin{array}{c}0.106 \\
(0.115)\end{array}$ & $\begin{array}{c}0.013 \\
(0.027)\end{array}$ & $\begin{array}{c}0.004 \\
(0.030)\end{array}$ & $\begin{array}{c}0.018 \\
(0.027)\end{array}$ & $\begin{array}{r}0.006 \\
(0.030)\end{array}$ \\
\hline Time Inconsistent & & $\begin{array}{l}-0.380^{*} \\
(0.226)\end{array}$ & & $\begin{array}{c}-0.341 \\
(0.234)\end{array}$ & & $\begin{array}{l}-0.070 \\
(0.060)\end{array}$ & & $\begin{array}{l}-0.061 \\
(0.064)\end{array}$ \\
\hline Interaction: Any Reminder * Time Inconsistent & & $\begin{array}{l}0.472^{*} \\
(0.259)\end{array}$ & & $\begin{array}{c}0.548 * * \\
(0.265)\end{array}$ & & $\begin{array}{c}0.070 \\
(0.067)\end{array}$ & & $\begin{array}{c}0.087 \\
(0.071)\end{array}$ \\
\hline Baseline Controls & No & No & Yes & Yes & No & No & Yes & Yes \\
\hline Mean of Dependent Variable & 2.531 & 2.531 & 2.531 & 2.531 & 0.204 & 0.204 & 0.204 & 0.204 \\
\hline $\mathrm{N}$ & 1547 & 1547 & 1547 & 1547 & 1547 & 1547 & 1547 & 1547 \\
\hline
\end{tabular}

${ }^{*} \mathrm{p}<0.10,{ }^{* *} \mathrm{p}<0.05,{ }^{* * *} \mathrm{p}<0.01$. Huber-White standard errors in parentheses. Reminder messages sent by text message. Regressions include controls for marketing offers in the Philippines (interest rate, joint/single account, deposit collection). Omitted variable is "no reminder." 


\section{RECENT WORKING PAPERS FROM THE}

\section{CENTER FOR RETIREMENT RESEARCH AT BOSTON COLLEGE}

The Shrinking Tax Preference for Pension Savings: An Analysis of Income Tax Changes, 1985-2007

Gary Burtless and Eric Toder, March 2010

Social Security, Benefit Claiming and Labor Force Participation: A Quantitative General Equilibrium Approach

Selahattin Imrohoroğlu and Sagiri Kitao, March 2010

How Much Is Enough? The Distribution of Lifetime Health Care Costs Anthony Webb and Natalia Zhivan, February 2010

Impact of Immigration on the Distribution of American Well-Being Gary Burtless, December 2009

Actual and Anticipated Inheritance Receipts

Norma B. Coe and Anthony Webb, December 2009

Will Automatic Enrollment Reduce Employer Contributions to 401(k) Plans Mauricio Soto and Barbara A. Butrica, December 2009

How Seniors Change Their Asset Holdings During Retirement Karen Smith, Mauricio Soto, and Rudolph G. Penner, December 2009

Retirement Security and the Stock Market Crash: What Are the Possible Outcomes?

Barbara A. Butrica, Karen E. Smith, and Eric J. Toder, November 2009

Fees and Trading Costs of Equity Mutual Funds in 401(k) Plans and Potential Savings from ETFs and Commingled Trusts

Richard W. Kopcke, Francis Vitagliano, and Zhenya S. Karamcheva, November 2009

Work Ability and the Social Insurance Safety Net in the Years Prior to Retirement Richard W. Johnson, Melissa M. Favreault, and Corina Mommaerts, November 2009

Dutch Pension Funds in Underfunding: Solving Generational Dilemmas Niels Kortleve and Eduard Ponds, November 2009

The Wealth of Older Americans and the Sub-Prime Debacle Barry Bosworth and Rosanna Smart, November 2009

All working papers are available on the Center for Retirement Research website (http://crr.bc.edu) and can be requested by e-mail (crr@bc.edu) or phone (617-5521762). 